\title{
Influence of Geographical and Historical Factors on Changes in Natural Features of Central Banat and the Quality of Ecosystem Services
}

\author{
Vesna Kicošev ${ }^{A}$, Jovan Romelić ${ }^{B}$, Milan Matavulj ${ }^{C}$, Ivo Marinić ${ }^{D}$, Anđelka BelićE \\ Received: March 17, 2015 | Revised: August 25, 2015 | Accepted: September 1, 2015
}

\begin{abstract}
Research of the influence of geographical and historical factors on changes in natural features and the quality of ecosystem services is important for the evaluation of the reference state of the quality of the environment and the potential of natural systems for the renewal of functions on which the wildlife on the planet depends. The territory of central Banat in the surrounding of protected areas "Slano Kopovo" Special Nature Reserve, "Rusanda" Nature Park and "Okanj Bara" Special Nature Reserve covering the settlements of Novi Bečej, Kumane, Melenci, Elemir and Taraš was selected for the analysis. Changes in ecosystems were monitored based on available geographical and historical data on the residence and activities of people in this territory during various time periods. Evaluation was conducted by scoring and gradation of impact was carried out by applying approximate values of spatial, qualitative and quantitative change indicators. According to the research results, current effects of the impact on the considered area were between significant and great. Results indicate the alarming state in the environment, since further increase in the scope of influences leads to the exceedance of capacities of the surrounding ecosystems for performing a part of ecosystem services (tremendous impact), or most of ecosystem services (drastic impact).
\end{abstract}

Key words: Banat, natural landscape features, ecosystem services.

\section{Introduction}

Through different functions, ecosystems perform services necessary for the survival of wildlife (De Groot, 1992; Costanza, et al, 1997; Daily, 1997; De Groot, et al, 2002; Brown, et al, 2007). Nowadays, the living creatures (including human beings) are adapted to living conditions which are the result of a large number of different interactions, both between the living species as well as with the elements of their habitats (Kicošev, Sabadoš, 2008). The study of different interactions in the environment and their impact on human wellbeing has been active for centuries (Johnson, 2000), and the notion of "ecosystem services" was defined while studying the cause and effect of disappearance of some species on the planet (Ehrlich, Ehrlich, 1981). Due to the intensification of regional and global environmental crises, the first attempts at the integration of data on the elements of biosphere within the United Nations project "Millennium Ecosystems Assessment" (MA, 2005a) were made at the end of the $20^{\text {th }}$ century.

\footnotetext{
A Institute for Nature Conservation of Vojvodina Province, Radnička 20a, Novi Sad, Republic of Serbia; vesna.kicosev@pzzp.rs

B Department of Geography, Tourism and Hotel Management, Faculty of Sciences, University of Novi Sad, Trg Dositeja Obradovića 3, Novi Sad, Republic of Serbia; jovan.romelic@gmail.com

c Department of Biology and Ecology, Faculty of Sciences, University of Novi Sad, Trg Dositeja Obradovića 2, Novi Sad, Republic of Serbia; milan.matavulj@dbe.uns.ac.rs

D Institute for industrialized building, Faculty of Technical Sciences, University of Novi Sad, Trg Dositeja Obradovića 6, Novi Sad, Republic of Serbia; marinicivo@sbb.rs

E Department of Water Management, Faculty of Agriculture, University of Novi Sad, Trg Dositeja Obradovića 6, Novi Sad, Republic of Serbia; anbel@polj.uns.ac.rs
} 
In it, four categories of services are recognised: supporting services (e.g. formation of land and a complex process of circulation of matter), provisioning services (possibility of obtaining food, water, material), regulating services (regulation of climate, hydrological processes, erosion and natural disasters, water purification and waste treatment) and cultural services (spiritual and aesthetical experience, recreation, possibility of formal and non-formal education). Based on the results of this project, deterioration of the state of biosphere has irreparable consequences for the ecosystem functionality and leads to the decline in biodiversity, which directly affects the quality of ecosystem services. The consequences of such changes also affect all economic activities which, directly or indirectly, depend on ecosystem services. In the first years of the period between 2000 and 2050, the estimated annual loss of ecosystem services will amount to 50 billion euros just from terrestrial ecosystems, while the cumulative welfare loss will be $70 \%$ of annual spending up to 2050 (REC, 2008).

One of the significant causes of changes in ecosystems is the land-use changes (EEA, 2010), and the impact on ecosystems is made by conversion, degradation and the change in spatial coherence (Leibowitz, et al., 200o), resulting in fragmentation, erosion, compression, increase in nutrient content (eutrophication), hazardous substances etc. (MA, 2005b). In the areas such as Vojvodina, with significantly modified natural features (EEA, 2002a), a great pressure is put on the functionality of ecosystems and their resistance to other influences is reduced (EEA, 2012). According to the data from the Regional Spatial Plan of the Autonomous Province of Vojvodina by 2020 , the remains of the natural and semi-natural arable agricultural land (pastures, reeds and swamps) cover only $7 \%$ of the territory which indicates their vulnerability to fragmentation. In terms of anthropogenic areas, $76 \%$ of the territory is covered by arable agricultural land and the share of the building land is about $12 \%$, which indicates the intensive land use (Kicošev et al, 2010). The natural vegetation of the steppe and forest areas is almost entirely destroyed and once vast wetlands have been reduced by drainage (Sabadoš, Panjković (eds.), 2009), whose importance for the sustainable development of the area is indicative (Stojanović, V., 2005). Economies of scale (quantity at the expense of diversity of species) led to the formation of uniform landscapes (Nassauer, Westmacott, 1987) and the loss of natural habitats such as meadows, field boundaries, protective belt of watercourses and clusters of trees which were the constituent part of arable ecosystems for centuries and represented an important source of genetic variations and adaptive characteristics. Ancestors and wild relatives of farmed animal species either disappeared or are highly endangered (FAO, 2007), which also contributed to the decline in biodiversity (Meeus, 1993). Protection of the remaining natural entireties which are more or less eligible for the preservation of rare and endangered organisms, preservation of biodiversity and the provision of ecosystem services is realised by establishing the ecological network of protected areas.

\section{Material}

The remaining fragments of natural habitats in the territory of Vojvodina are included into the protected areas and represent a part of the national ecological network. Pannonian types of salt habitats (Pannonian salt steppes and salt marshes, EUNIS classification: E6.21) (EEA, 2002b), represent significant elements of the national ecological network. Pannonian salt steppes and salt marshes, which were one of the dominant types of primeval vegetation of Vojvodina, were valued (under code: 1530) as priority habitats for protection in the neighbouring countries of the European Union (Directive on Habitats - Directive 92/43/ EEC Annex I). The largest portion of these types of habitat can be found in the form of smaller or larger fragments in the area of Banat, with a significant part of it under protection or undergoing the protection procedure. The territory of central Banat in the surrounding of protected areas "Slano Kopovo" Special Nature Reserve, "Rusanda" Nature Park and "Okanj Bara" Special Nature Reserve covering the settlements of Novi Bečej, Kumane, Melenci, Elemir and Taraš (Figure 1) was selected for the analysis.

Based on the effects of the changes in natural features of the area and ecosystem services, there is a period in which extensive use of most resources dominates as well as a period of intense urban and economic development.

Period of extensive use of space: For a long period of time Banat was the area of meandering flow of the Tisa, Moriš, Zlatica, Begej, Tamiš, Brzava, Moravica, Karaš and Nera and their armlets, bayous and ponds with spacious pastures, numerous groves, sand dunes and scarcely populated settlements (Cerović, 1984). The Tisa River had defensive and economic importance as early as in the prehistory (Grubić, 2010) and its flooding area (up to $8 \mathrm{~km}$ in width) included numerous gullies and pits filled with water until mid-summer (Varadinac, 2001). Ever since the Neolithic period, the population in this area has been engaged in fishing, fruit collection and big-game hunting and archaeological finds from the Aradac-Elemir area indicate the presence of first settlements and use of clay for the development of pottery during the middle Neolithic period (Marinković, 2010). Compris- 


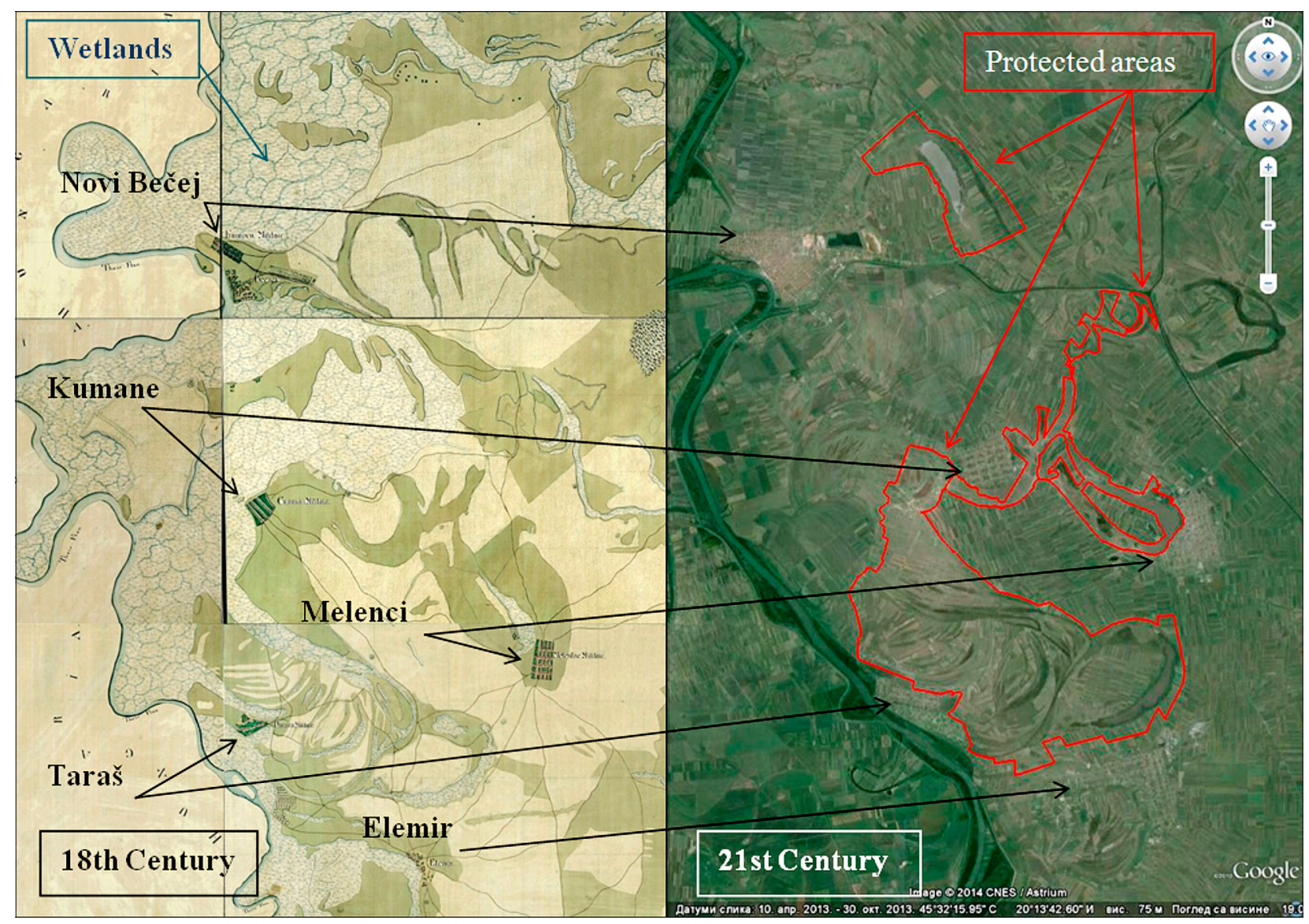

Figure 1. Graphic representation of the area on the map of the first military survey of the Austro-Hungarian Empire (1769-1772.) and Google Earth maps (2014).

Source: http://en.wikipedia.org/wiki/File:Banat_Josephinische_Landaufnahme_pg062.jpg; Google Earth maps.

ing many research results, Sümegi (2011) concludes that the wild species of large herbivores disappeared around the middle Bronze Age and their place was replaced by domestic livestock. People living on higher ground along the flooding areas during the Bronze Age and during the Sarmatian period engaged in cattle breeding, which led to the continuous reduction in the area of alluvial forests. Regular grazing was one of the main reasons for making restoration of the forest area within the forest-steppe vegetation on higher ground impossible and which led to the spreading of the steppe (Sümegi, 2011). At the beginning of the second millennium, pastures remained the dominant elements of the area with cultivated land covering only a small portion of that area (Frisnyák, 2004). There was a similar situation during the settling of Slavs in the $6^{\text {th }}$ century (who mainly engaged in fishing and cattle breeding and pottery in the $7^{\text {th }}$ century).

Due to the large wetland areas (Figure 1) and frequent wars in this territory, until the $18^{\text {th }}$ century Banat was scarcely populated area and regarded as neglected in agrarian sense. Farming intensified as late as in the 18th century during the systematic colonisation of Banat (Grošin, 2009). Crop rotation was not applied in land cultivation and manure and ash were used. Af- ter 1718 , by order from Vienna, trenching, river regulation and road construction commenced and the land was divided into sessional (old land), marshland (iberland, reserve) and heath (Cerović, 1984). Lots of old land and heath were sold for agricultural production as early as in 1770/80 (Dostanić and Zebić, 2002), and after the regulation of the Tisa (1850-1875), the construction of embankments and cutting of meander, iberland also became arable. The increase in the yield of crops (primarily wheat) influenced the necessity for stone silo construction, primarily in the coastal area of the Tisa due to the facilitated water transport (Mečkić, 1998). After the settling of Germans, agronomy was developed, the compulsory crop rotation was introduced and each household obtained some space for the cultivation of fruit and vegetables. Silkworms and mulberry were cultivated in the settlements (Brusin, 1995). Willow tree groves dominated in the wetlands, while poplars, Lombardy poplars and elms were sporadically planted on the fields. At the beginning, mounds were the delimiter between the land lots and in the second half of the 19th century, fallow land called fund (boundary) was used as the delimiter, 1-2 steps in width and overgrown by natural vegetation. For agricultural purposes, the land was divided into three parts: spring, autumn sowing 
and for the purpose of grazing (Grubić, 2010). The land was prepared by ploughing horses, sowing was carried out manually, sickles were used for mowing and the weed was eradicated by hand tool (Grošin, 2009). In the earliest documents (from 1784, 1792, 1826), among the crafts, innkeepers, butchers and merchants are mentioned and at the beginning of the $2 \mathrm{O}^{\text {th }}$ century, blacksmiths, cartwrights and other occupations were registered (Dostanić, Zebić, 2002). After the construction of the spa complex in Melenci (1878 - 1932), the extensive development of health tourism commenced due to the use of the healing peloid (Tomić, Romelić, 2004).

Period of intensive use of space: In the second half of the $19^{\text {th }}$ century, iberland was particularised once again after which the process of augmentation of small rural households started in order to intensify agriculture (Popović, 1955; Cerović, 1984). This period witnessed the attempts to afforest salt lands of Banat. After the activation of waterways, the construction of the railways (1881-1883), improvement of the road network as well as the formation of bank capital, the development of industry intensified in this part of Banat. By the end of the $19^{\text {th }}$ century, the opulent steppe vegetation of the higher river terrace was turned into arable land and in the following period, the highest sections of the beams in the salt lands were being ploughed over. As the land owners and buyers of products became more interested in intensive agriculture, the more was invested into the production and the development of the agricultural machinery. In the early $20^{\text {th }}$ century, the first tillage equipment was used, some of which (for instance, the roller) weighing up to $300 \mathrm{~kg}$. The fertilizer was also introduced (superphosphate, potassium salt, Chilean saltpetre, NPK mixture etc.) (Grubić, 2010). The development of industrial production commenced in the late $19^{\text {th }}$ century and at the beginning of the $2 \mathrm{O}^{\text {th }}$ century in the form of plants for the production of building material and food, textile and chemical industries (production of denatured alcohol and soap) and so forth (Petrović, 2010). The construction of the railway line was of benefit to the development of economy while economic prosperity was boosted by the construction of a mill (1910) and a brickyard (1900 and 1911) (Cerović, 1984) in the vicinity of Rusanda Lake. A brickyard was built in 1907 near Novi Bečej which used clay from the sites near Slano Kopovo.

Between the two World Wars, castor oil plant, hemp, sorghum and rape seed were cultivated and more intensive vegetable growing commenced and up until 1960 s, old varieties of wheat and corn were grown. The increase in the yield influenced the need for the construction of drying facilities and windmills (Grošin, 2009), and later mills and silos (Dostanić, Zebić, 2002). The vines were grown in the loose sandy soil stretching from the settlement towards the Tisa and on the sandy beams and vineyards were treated with blue stone and lime. The agrarian reform after the First World War kept the large estates with intensive tillage manner, followed by a series of futile attempts at "purposeful utilisation" of the salty soil (Cerović, 1984). The agrarian reform from the socialist period (establishment of peasant cooperatives, grouping of estates) and use of pesticides represented another contribution to the continuation of the intensive crop production (Varadinac, 2001). Crop production was followed by intensive livestock farming in settlements, with the first great poultry farm built near Melenci in 1959 (today a broiler farm of the "Perutnina" Ptuj Company). Intensive fish farming near Melenci was started in 1965 by "Ečka" Company thus turning "Ostrovo" salinified lake into a eutrophic freshwater body.

The pace of the 196 os speeded up the development of industry, primarily the continuation of the exploration of oil and gas which commenced during 1942 and 1943 by the German company "Petrol A.G..". Exploitation from the oil and gas fields in the Cadastral Municipality of Elemir was initiated in 1959 after the establishment of "Naftagas" Company. In the vicinity of Elemir, gas and oil collection and distribution stations SS1 (1960) and SS2 (1961) were built. In 1963, the "Tisa" Loading Station was built in Elemir for receiving oil from reservoirs and in the same year, NIS GAS - Gas Refinery Company was established, whose main activity was processing the natural gas from oil and gas reservoirs (Tomić and Romelić, 2003). The first petrol station was built in Kumane in 1975. Immediately after the war, the "Mlekoprodukt" milk industry was established in Novi Bečej, which started operating intensively as late as in 1965, after the reconstruction (Tomić and Romelić, 2003). In the 1960's, intensive production of bricks and tiles was initiated in the industrial zone of Novi Bečej by "Polet" Company (ceramic tile factory which began operations as late as in 1980). The development of the food industry in this area continued in 1963 after the construction of "Žitoprerada" complex (with a new mill and confectionery industry). From 1975 onwards, a refrigerator for agricultural products was built within the complex of the "Sokolac" farm in Novi Bečej and in 2014, economic offence proceedings were initiated against the current owner (D.O.O. TT" from Novi Sad) for irregular treatment of the environment. In the same year (1975) "Tools and Machines Factory" - FAM (presentday "Vogel") was put into operation, which in the past decade has been operating with reduced production volume. Since 1976, a plant for the final processing of material within the textile industry (former "Kluz") has been operating. In the vicinity of the industrial zone (within the paleomeander of the Tisa where Slano Kopovo is located), a dump of the Novi Bečej 
settlement was formed which has been used as a location for the municipal waste disposal from all settlements of this municipality ever since 2007. "Biser" chemical industry (the only industrial complex in the Kumane settlement), whose basic scope of activities includes the production of cosmetics, household and industrial chemicals, was put into operation in 1980. After the provision of new equipment in 2002, the production intensified (Tomić, Romelić, 2003), but ever since 2008 , the company has been operating with extremely reduced capacity. The HIP "Synthetic Rubber Factory" whose main activity is the production of styrene-butadiene rubber was put into operation in the Elemir settlement in 1984. In 1990, "Naftagas" Company continued with its oil (Melenci oilfield) and gas exploration (fields "Rusanda plitko" and "Melenci duboko" and in the very same year, Oil and Gas Collection Point was built in the territory of the Melenci Cadastral Municipality. In 2002, Collection and Dispatch Station was built. Currently, new oil and gas exploration is being carried out by "NIS Gazprom Neft". Since 1990, "Mašinopromet" company for the production of equipment for food, beverages and tobacco has been operating in Elemir and in 1998, "Mlekoprerada" started its production of dairy products. In this period (since 1997) a slaughter plant was put into operation in Novi Bečej. Since 2013, a shipyard of the "LBM" Company from Zrenjanin has been using this area along the DTD canal (which supplies Slano Kopovo with water) but due to irregular business operation, it was banned from operating by inspection service in the area of environmental protection.

\section{Methods}

Changes in ecosystems were monitored based on available geographical and historical data on the residence and activities of people in this territory during various time periods. Ever since the time people first appeared in this area up to now, the impact on the environment has been intensifying, with temporary or permanent effects on the natural values of the area because of the use of available instruments and techniques during different time periods and application of new findings on the possibilities of using land and other resources. Evaluation of these changes as well as the quality of ecosystem services was conducted by considering the impacts of key anthropogenic factors (Table 1) which affect the state of biodiversity, fragmentation, changes in microclimatic conditions, water regime and land use as well as some forms of pollution. Evaluation was conducted by scoring (1-7), wherein an increase in the value of a point represents an increase of adverse effects which results in the deterioration of the state of natural features of landscapes.
This deterioration is reflected on the changes in the quality of ecosystem services. Gradation of impact (insignificant, small, lower medium, higher medium, significant, great, tremendous, drastic) was carried out by applying approximate values of spatial, qualitative and quantitative change indicators. Consideration of spatial indicators (approximate reduction of the area covered by wetlands and other natural habitats due to the increase in arable land and building area) had a key role in evaluating the fragmentation level, change in the water regime and intensity of land use. Consideration of qualitative and quantitative indicators (in terms of types of substances and assumed quantity) is significant for the evaluation of nutrient impact which occurs as eutrophication, effect of dangerous substances, greenhouse gases (GHG) and other substances whose emission from different sources has an impact on global changes in the biosphere. Each of the given factors influences the state of biodiversity to a smaller or greater extent. Their combination (most often their synergistic effect) reduces the quality of ecosystem services.

\section{Results}

Evaluation of effects of changes in natural landscape features and ecosystem services is shown in Table 1. The insignificant impact on natural landscape features and ecosystem services was found in the case of occasional presence of people, that is, when their activities could not have measurable effects on monitored parameters and this is primarily related to the Stone Age (Neolithic period) and the Bronze Age. Influences with dominant small and medium impacts refer to the period up until the beginning of the 19th century when significant alterations in landscape features of the abovementioned area occurred due to the activities pertaining the regulation of the Tisa, intensive wetland drainage, pressures on soil habitats as well as the expansion of building areas, road network and so on. Influences with great impact characterise the period of the construction of industrial complexes and supporting infrastructure, intensive resource exploitation and emission of pollutants into the environment.

Evaluation of small and medium impacts on natural landscape features is influenced by the approximate scope of work (primarily in the area of agriculture), intensity of construction and the manner in which resources are used. For instance, fragmentation of forest habitats is influenced more by deforestation on larger portions of land than cutting of trees; fragmentation of steppe habitats depends on the size and type of disturbed area and the fragmentation of wet habitats is additionally related to the drainage intensity and the manner of land tillage. Along with the increase in frag- 
Table 1. Graphic representation of the effects of the changes in natural features and ecosystem services. Source: Authors research.

\begin{tabular}{|c|c|c|c|c|c|c|c|c|c|c|}
\hline $\begin{array}{c}\text { Key time } \\
\text { periods }\end{array}$ & Neolithic & Bronze Age & $\begin{array}{l}\text { VI-VII } \\
\text { century }\end{array}$ & $\begin{array}{l}\text { XI-XVI } \\
\text { century }\end{array}$ & $\begin{array}{l}\text { XVIII c } \\
\text { I half }\end{array}$ & $\begin{array}{c}\text { XVIII c } \\
\text { II half }\end{array}$ & $\begin{array}{l}\text { XIX c } \\
\text { I half }\end{array}$ & $\begin{array}{l}\text { XIX c } \\
\text { II half }\end{array}$ & $\begin{array}{l}\text { XX c } \\
\text { I half }\end{array}$ & $\begin{array}{r}\mathbf{X X} \text { century } \\
\rightarrow \mathbf{X X I} \\
\end{array}$ \\
\hline $\begin{array}{c}\text { Human } \\
\text { presence and } \\
\text { activities which } \\
\text { directly affects } \\
\text { the changes in } \\
\text { natural features } \\
\text { and the quality } \\
\text { of ecosystem } \\
\text { services }\end{array}$ & $\begin{array}{l}\text { Temporary } \\
\text { human } \\
\text { presence } \\
\text { Fishing } \\
\text { Fruit } \\
\text { collection } \\
\text { Big-game } \\
\text { hunting } \\
\text { Use of clay }\end{array}$ & $\begin{array}{l}\text { First small } \\
\text { settlements } \\
\text { Decline in } \\
\text { abundance } \\
\text { \& diversity } \\
\text { of wild } \\
\text { species } \\
\text { Breeding of } \\
\text { domestic } \\
\text { animals } \\
\text { Lumbering } \\
\text { Increasing } \\
\text { of steppes } \\
\text { Use of clay }\end{array}$ & $\begin{array}{l}\text { Settlements } \\
\text { increment } \\
\text { Decline in } \\
\text { wild species } \\
\text { Domestic } \\
\text { animals } \\
\text { increasing } \\
\text { Deforestat. } \\
\text { Steppe } \\
\text { plowing } \\
\text { Use of clay }\end{array}$ & $\begin{array}{l}\text { Settlements } \\
\text { increasing } \\
\text { Decline in } \\
\text { wild } \\
\text { species } \\
\text { Domestic } \\
\text { animals } \\
\text { and arable } \\
\text { land } \\
\text { increasing, } \\
\text { Steppe } \\
\text { decreasing } \\
\text { No land- } \\
\text { use plans } \\
\end{array}$ & $\begin{array}{c}\text { Planned } \\
\text { settlements } \\
\text { formation } \\
\text { Domestic } \\
\text { animals } \\
\text { and arable } \\
\text { land } \\
\text { increasing } \\
\text { Wetland } \\
\text { drainage } \\
\text { No arable } \\
\text { land-use } \\
\text { plans }\end{array}$ & $\begin{array}{l}\text { Settlements } \\
\text { spreading } \\
\text { Land lots } \\
\text { joining } \\
\text { for mono- } \\
\text { cultures } \\
\text { growing } \\
\text { Arable land } \\
\text { instead of } \\
\text { steppes and } \\
\text { wetlands } \\
\text { Stone silo } \\
\text { for slather } \\
\text { of crops } \\
\end{array}$ & $\begin{array}{c}\text { Cutting of } \\
\text { meander } \\
\text { Construct. } \\
\text { of emba- } \\
\text { nkments } \\
\text { Settlements } \\
\text { and roads } \\
\text { increasing } \\
\text { Intensive } \\
\text { iberland } \\
\text { tillage } \\
\text { Mills } \\
\text { Land-use } \\
\text { planning }\end{array}$ & $\begin{array}{c}\text { Intensive } \\
\text { arable land } \\
\text { drainage } \\
\text { Salt land } \\
\text { afforestat. } \\
\text { Crop rotat. } \\
\text { Land lots } \\
\text { delimiters - } \\
\text { natural } \\
\text { vegetation } \\
\text { Spa compl. } \\
\text { "Rusanda", } \\
\text { Railways } \\
\text { construct. }\end{array}$ & $\begin{array}{l}\text { Intensive } \\
\text { use of clay } \\
\text { Metal } \\
\text { processing } \\
\text { Agriculture } \\
\text { mechanisa- } \\
\text { tion use } \\
\text { Fertilizer- } \\
\text { NPK etc. } \\
\text { Salt land } \\
\text { utilisation } \\
\text { Oil and gas } \\
\text { exploitat. }\end{array}$ & 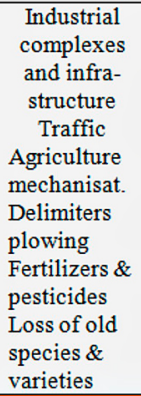 \\
\hline \multicolumn{11}{|l|}{ Biodiversity } \\
\hline \multicolumn{11}{|l|}{ Fragmentation } \\
\hline \multicolumn{11}{|l|}{ Microclimate } \\
\hline \multicolumn{11}{|l|}{ Water regime } \\
\hline \multicolumn{11}{|l|}{ Land use } \\
\hline \multicolumn{11}{|l|}{ Eutrophication } \\
\hline \multicolumn{11}{|l|}{ GHG and other } \\
\hline \multicolumn{11}{|l|}{ Dangerous sub. } \\
\hline Ecosystem serv. & & & & & & & & & & \\
\hline
\end{tabular}

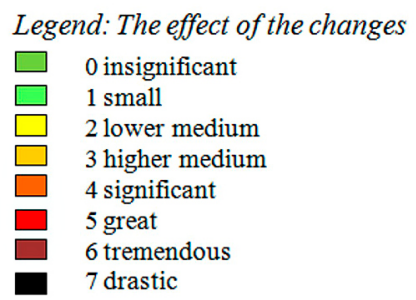

mentation of natural habitats, an increase in the builtup area and reduction of vegetation coverage, the drop in the number and diversity of species is also detected, as well as the change in water regime, deterioration of microclimatic conditions, rise in the pollution rate, occurrence of erosion etc. On the one hand, by destroying forests and plowing steppe habitats, ecosystem services of retaining the particle pollution and gas absorption are lost and on the other hand, huge amounts of carbon dioxide (which has always been bound in the soil substrate) are emitted. This impact is most evident when salt habitats are plowed (which happens even nowadays) since these types of habitat represent significant greenhouse gases reservoirs and sinks. As a result of the loss of natural habitats and the increase in the area under single-crops, the quality of water treatment ecosystem services diminishes as well as the dissolution of waste material etc. The use of fertilisers and pesticides and the use of mechanisation in the land tillage affect the content and distribution of pollutants and have adverse effects on the survival of species which have the key role in their decomposition. Exploitation of minerals (e.g. clay) changes the water regime and habitat conditions, indirectly affecting the diversity of species and habitat types. Finally, the construction and operation of industrial complexes have a negative long-term and cumulative effect on all the abovementioned elements. Influences with great impact are here represent- ed in a red colour which indicates an alarming situation since further increase in the scope of influences leads to the exceedance of capacities of the surrounding ecosystems for performing a part of ecosystem services (immense impact), or most of ecosystem services (drastic impact). Consequences of immense impacts (level 6) could be remediated in the long term with significant financial investments, while the consequences of drastic impacts (level 7) are irreversible, which basically means that ecosystems in such cases permanently lose their ability to perform services (Figure 2).

In the past few years, some of the existing production complexes have been operating with reduced capacity (some of them have been closed down) and the construction of new industrial facilities is mainly related to the service activity. However, this does not mean that in the future we should expect some improvement regarding the ecosystem services. Changes in natural systems which emerged under the influence of endangering factors such as pollution can show their effects on ecosystem services only after a longer period of time. Due to delayed effects of influences from the previous period, their cumulative and mostly synergistic impact on ecosystems, the situation in the environment can still be considered alarming without additional pressure on the environment. On the other hand, with expected investments in the development of economy (primarily agriculture) in 


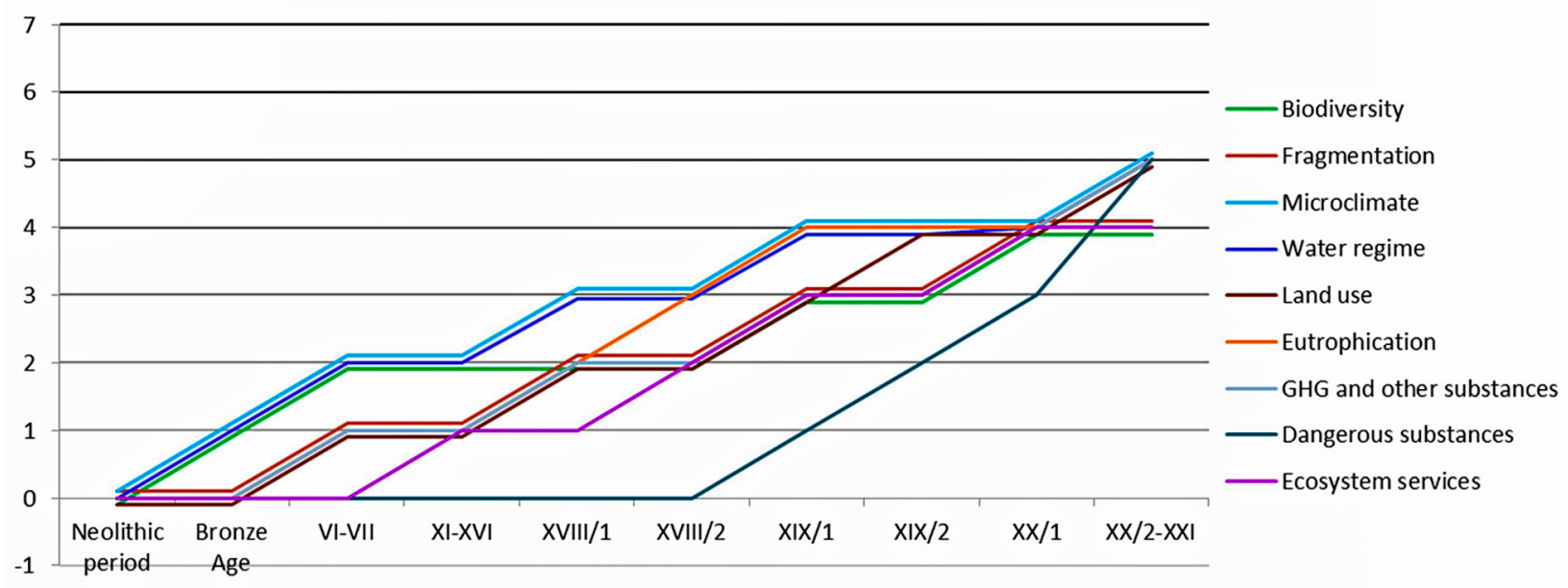

Figure 2. Graphic representation of the effects of human impacts on natural environment. Source: Authors research.

the territory of Vojvodina, and lacking the proper application of measures for sustainable use of resources, we can expect that the effects of the pressure on the remaining natural habitats shall be far greater than the potential investment in the consequences of the losses.

\section{Discussion}

Due to the lack of detailed information on the changes in landscape which occurred during the occupation of the Banat area by people, the obtained data represent a rough account of effects on natural habitats. However, the analysis results may be a useful basis for considering the reference condition of the environment and capacities of ecosystems for providing services, especially when we bear in mind the potential costs of rehabilitation of consequences resulting from the impact of human activities on the environment. For instance, the cost of the recovery of one hectare of land from the results of intensive agricultural production varies from $\$ 528$ to $\$ 617$ (Phillips (ed.), 1998). On the other hand, economic value of the converted land is often far lower than sustainably used natural systems which provide greater diversity and quality of services (Athanas et al., 2006). Costs of habitat restoration from the effects of eutrophication amount to $\$ 75.000 / \mathrm{km} 2$ for the removal of nitrogen compounds and $\$ 12133 / \mathrm{km} 2$ for the removal of phosphorus compounds (Kettunen, ten Brink, 2006). According to calculations (Mani et al., 2008), estimated annual costs of adaptation to global changes vary from 4-109 billion dollars for the developing countries and between 44 and 166 billion dollars at the global level. Funds necessary for future adaptation to consequences of global changes pose a significant financial burden even for economically developed countries and for countries such as Serbia, they might be an unattainable goal. For the abovementioned reason, maintenance of the natural capacity of ecosystems for provid- ing services is most often far cheaper than investing in alternative technological solutions (where there is such alternative) (Dudley and Stolton, 2003).

Preservation of natural habitats of ecological network of protected areas results in numerous social and economic benefits (IEEP, 2002; ten Brink et al., 2002). If a whole range of provided ecosystem services is taken into account, benefits from the protected area often exceed the costs (ten Brink et al., 2009). Ecotourism with organic food production was described as the fastest-growing economic sector in the world, with annual revenues exceeding 100 billion dollars (TIES, 2005). Data from Scotland pertaining to the areas under Natura 2000 Ecological Network of the European Union prove that the public benefits of protection are more than three times higher than the costs (Jacobs, 2004). Integration of the programme of preservation of biodiversity and protected areas in the regional and local planning can even result in greater benefits from the ecosystem services in this area (Kettunen, ten Brink, 2006).

\section{Conclusion}

Through different functions, ecosystems perform services necessary for the survival of wildlife. Human activities pertaining to the modification of natural habitats influence the functionality of ecosystems and the consequences of these influences directly affect the quality of ecosystem services. The territory of central Banat in the surrounding of protected areas "Slano Kopovo" Special Nature Reserve, "Rusanda" Nature Park and "Okanj Bara" Special Nature Reserve covering the settlements of Novi Bečej, Kumane, Melenci, Elemir and Taraš was selected for the analysis. Changes in ecosystems were monitored based on available geographical and historical data on the residence and activities of people in this territory during various time periods. Evaluation was conducted by scoring (1-7), and 
gradation of impact (insignificant, small, lower medium, higher medium, significant, great, tremendous, drastic) was carried out by applying approximate values of spatial, qualitative and quantitative change indicators. The insignificant impact on natural landscape features is mostly related to the Neolithic period and the Bronze Age. Influences with dominant small and medium impacts refer to the period up until the beginning of the $19^{\text {th }}$ century when significant alterations in landscape features of the abovementioned area occurred. Influences with great impact characterise the period of the construction of industrial complexes and supporting infrastructure, intensive resource exploitation and emission of pollutants into the environment. Current effects of the impact on the considered area were between significant and great.

The analysis results may be a useful basis for considering the reference condition of the environment and capacities of ecosystems for providing services, especially when we bear in mind the potential costs of rehabilitation of consequences resulting from the impact human activities have on the environment. Funds necessary for future adaptation to consequences of global changes pose a significant financial burden even for economically developed countries and for countries such as Serbia, they might be an unattainable goal. For the abovementioned reason, maintenance of the natural capacity of ecosystems for providing services is most often far cheaper than investing in alternative technological solutions. Preservation of natural habitats of ecological network of protected areas results in numerous social and economic benefits. Integration of the programme of preservation of biodiversity and protected areas in the regional and local planning can even result in greater benefits from the ecosystem services in this area.

\section{References}

Athanas, A., Bishop, J., Cassara, A., Donaubauer, P., Perceval, C., Rafiq, M., Ranganathan, J., Risgaard, P. 2006. Business and Ecosystems: Ecosystems Challenges and Business Implication, Switzerland: Earthwatch Institute, World Resources Institute, World Bussines Council for Sustainable Development and World Conservation Union.

Brown T.C., Bergstrom J.C. and Loomis J.B. 2007. Defining, valuing, and providing ecosystem goods and services. Natural Resources Journal 47-2, 329-376.

Brusin, M. 1995. The life of our ancestors: Kumane, Novi Sad: Matica srpska. (in Serbian)

Cerović, Lj. 1984. Chronicle of Melenci 1751-1941, progressive and revolutionary movement. Mesna zajednica Melenci, Mesna konferencija SSRNV Melenci, Zavičajno društvo Melenci. (in Serbian)
Costanza R., D’Arge R., De Groot R., Farber S., Grasso M., Hannon B., et al. 1997. The value of the world's ecosystem services and natural capital. Nature 387 , 253-260.

Daily G.C. 1997. Introduction: What are ecosystem services? In: Daily GC (ed.) Nature's Services: Societal Dependence on Natural Ecosystems. Washington, DC: Island Press, 1-10.

De Groot R.S. 1992. Functions of Nature: Evaluation of Nature in Environmental Planning, Management and Decision Making. Groningen: WoltersNoordhoff.

De Groot R.S., Wilson M.A. and Boumans R.M.J. 2002. A typology for the classification, description and valuation of ecosystem functions, goods and services. Ecological Economics 41-3, 393-408.

Dostanić, M., Zebić, M.M. 2002. It is Taraš: Chronicle of a long-standing village. Mesna zajednica Taraš. (in Serbian)

Dudley, N., Stolton, S. 2003. Running Pure: The importance of forest protected areas to drinking water, World Bank /Alliance for Forest Conservation and Sustainable Use, Switzerland: WWF. URL: http://assets.panda.org/downloads/runningpurereport.pdf

EEA-European Environment Agency, 2002a. The Pannonian region in Europe's biodiversity - biogeographical regions and seas. Luxembourg: Publications Office of the European Union.

EEA-European Environment Agency, 2002b. EUNIS Hábitat Classification Web Application. URL: http://eunis.eea.europa.eu/

EEA-European Environment Agency, 2010. Towards a resource-efficient transport system. Luxembourg: Publications Office of the European Union.

EEA-European Environment Agency, 2012. Environmental indicator report: Ecosystem resilience and resource efficiency in a green economy in Europe, Luxembourg: Publications Office of the European Union.

Ehrlich, P.R. and Ehrlich, A.H. 1981. Extinction: the causes and consequences of the disappearance of species. 1st edition. New York: Random House, 305 pp.

FAO, 2007. The State of the World's Animal Genetic Resources for Food and Agriculture (B. Rischkowsky, D. Pilling, Eds.), Rome: Food and Agriculture Organization of the United Nations.

Frisnyák, S. 2004. Csihák Gy. szerk., Gyepűk, várak és egyéb védelmi létesítmények a Kárpát-medencében. Zürich-Nyíregyháza, 103-113 pp.

Grošin, D. 2009. Melencze, Frame of local, social and family life 1751-1918. Istorijski arhiv Kikinda. (in Serbian)

Grubić, R. 2010. Agriculture in the Banat region until the middle of the twentieth century. Banat kroz vekove: Slojevi kultura Banata. Zbornik radova, Beograd: Vukova zadužbina, 905-927. (in Serbian) 
IEEP, 2002. Proceedings of the European Conference on Promoting the Socio-Economic Benefits of Natura 2000, Brussels: Institute for European Environmental Policy (IEEP), 22 pp.

Jacobs, NFO World Group 2004. An Economic Assessment of the Costs and Benefits of Natura 2000 Sites in Scotland. Final Report. URL: http://www. scotland.gov.uk/Resource/Doc/47251/0014580.pdf

Johnson, D.G., 2000. Population, food, and knowledge. American Economic Review 90-1, 1-14.

Kettunen, M., ten Brink, P. (eds) 2006. Value of biodiversity- Documenting EU examples where biodiversity loss has led to the loss of ecosystem services. Final report for the European Commission. Brussels: Institute for European Environmental Policy (IEEP). $131 \mathrm{pp}$.

Kicošev, V., Sabadoš, K. 2008. Implementation of principles of sustainability in spatial planning in Vojvodina, Zaštita prirode, Beograd: Zavod za zaštitu prirode Srbije, 501-510. (in Serbian)

Kicošev, V., Sabadoš, K., Kišs, A. 2010. Air quality improvement in the Pannonian region by implementaion of international agreements on the development of Pan-European Ecological Network. Zaštita vazduha, Beograd: Privredna komora Srbije, 21-24 pp. (in Serbian)

Leibowitz, S.G., Wiley, M.J., Li, B.L. J. Preston, E.M. 200o. Modeling landscape functions and effects: a networkapproach. Ecological Modelling 132, 77-94.

Mani, M., Markandya, A., Ipe, V. 2008. Policy and Institutional Reforms to Support Climate change Adaptation and Mitigation in Development Programs A Practical Guide, The International Bank for Reconstruction and Development / The World Bank, Environment Department Sustainable Development Network.

Marinković, S. 2010. Banat in prehistory, antiquity and during the people's migrations. Banat kroz vekove: Slojevi kultura Banata. Zbornik radova, Beograd: Vukova zadužbina, 15-32. (in Serbian)

Mečkić, L. 1998. Let us be reminded of Novi Bečej and its inhabitants. Beograd (in Serbian)

Meeus, J. H. A. 1993. The transformation of agricultural landscapes in Western Europe. The Science of the Total Environment 129, 171-19o.

Millennium Ecosystem Assessment (MA) 2005a. Ecosystems \& Human Well-being: Wetlands \& Water. World Resources Institute, Washington DC.

Millennium Ecosystem Assessment (MA) 2005b. Ecosystems \& Human Well-being: Summary for decision makers. Island Press, Washington DC.

Nassauer, J. I., Westmacott, R. 1987. Progressiveness among farmers as a factor in heterogeneity of farmed landscapes. In Landscape Heterogenei- ty and Disturbance (M.G. Turner, ed.), New York: Springer-Verlag. 99-210 pp.

Petrović, D. 2010. Industrialization of Banat. Banat kroz vekove: Slojevi kultura Banata. Zbornik radova, Vukova zadužbina: Beograd, 929-942 pp. (in Serbian)

Phillips, A. (ed.) 1998. Economic Values of Protected Area: Guidelines for Protected Area Managers, UK: Cardiff University, World Commission on Protected Areas, The World Conservation Union.

Popović, D. 1955. Serbs in Banat by the end of the 18th century, The history of settlements and population. Srpska akademija nauka: posebna izdanja, Etnografski institut, knjiga 6. Beograd: Naučna knjiga. (in Serbian)

REC -Regional Environmental Centre 2008. Climate change and biodiversity in South-East Europe. Sažet rezime naučnog i političkog konteksta, problemi i preporučene aktivnosti. Tilburg: ECNC (European Centre for Nature Conservation). (in Serbian)

Sabadoš, K.., Panjković, B. (eds) 2009. Establishing the ecological network in AP Vojvodina- Review of the state, analysis and possibilities. Studija, Novi Sad: Zavod za zaštitu prirode Srbije. (in Serbian)

Stojanović, V. 2005. Degradation and Protection of Wetlands in Special Nature Reserves in Vojvodina. Geographica Pannonica 9, 24-28.

Sümegi P. 2011. Az Alföld élővilágának fejlődése a jégkor végétől napjainkig, In: Rakonczai J (szerk.) Környezeti változások és az Alföld. 396 p. Békéscsaba: Nagyalföld Alapítvány, 35-44 pp.

ten Brink, P., Berghöfer, A., Schröter-Schlaack, C., Sukhdev, P., Vakrou, A., White, S., Wittmer, H. 2009. TEEB - The Economics of Ecosystems and Biodiversity for National and International Policy Makers Summary: Responding to the value of nature, Germany: United Nations Environment Programme

ten Brink, P., Monkhouse, C., Richartz, S. 2002. Background Report for European conference on Promoting the Socio-Economic Benefits of Natura 2000, Brussels: Institute for European Environmental Policy (IEEP), $28 \mathrm{pp}$.

TIES (The International Ecotourism Society). 2005. URL: http://www.ecotourism.org

Tomić, P., Romelić, J. 2003. Banat: Industrija Banata (Banat: Industry of Banat), Geografski aspekti stanja i pravaca razvoja Srbije (Vojvodine), Naučna monografija. Departman za geografiju, turizam i hotelijerstvo. Novi Sad: PMF (Prirodnomatematički fakultet).

Tomić, P., Romelić, J. 2004. Features and Exploitation of Thermal-Mineral Water in the Yugoslav Banat. Geographica Pannonica 4, 26-30.

Varadinac, R. 2001. Kumane in sport and culture 19471997. Mesna zajednica Kumane. (in Serbian) 